\title{
Integrin activation is an essential component of SARS-CoV-2 infection
}

\author{
Peter Simons ${ }^{1}$, Derek A. Rinaldi ${ }^{1}$, Virginie Bondu ${ }^{2}$, Alison M. Kell ${ }^{2,4}$, Steven Bradfute ${ }^{3,4}$, \\ Diane S. Lidke ${ }^{1,5} \&$ Tione Buranda ${ }^{1,4} \bowtie$
}

SARS-CoV-2 infection depends on binding its spike (S) protein to angiotensin-converting enzyme 2 (ACE2). The $S$ protein expresses an RGD motif, suggesting that integrins may be co-receptors. Here, we UV-inactivated SARS-CoV-2 and fluorescently labeled the envelope membrane with octadecyl rhodamine $B(R 18)$ to explore the role of integrin activation in mediating cell entry and productive infection. We used flow cytometry and confocal microscopy to show that SARS-CoV-2 ${ }^{\mathrm{R} 18}$ particles engage basal-state integrins. Furthermore, we demonstrate that $\mathrm{Mn}^{2+}$, which induces integrin extension, enhances cell entry of SARS-CoV-2 ${ }^{\mathrm{R} 18}$. We also show that one class of integrin antagonist, which binds to the $\alpha$ I MIDAS site and stabilizes the inactive, closed conformation, selectively inhibits the engagement of SARS-CoV-2 ${ }^{\mathrm{R} 18}$ with basal state integrins, but is ineffective against $\mathrm{Mn}^{2+}$-activated integrins. RGD-integrin antagonists inhibited SARS-CoV-2 ${ }^{\mathrm{R} 18}$ binding regardless of integrin activation status. Integrins transmit signals bidirectionally: 'inside-out' signaling primes the ligand-binding function of integrins via a talin-dependent mechanism, and 'outside-in' signaling occurs downstream of integrin binding to macromolecular ligands. Outside-in signaling is mediated by $\mathrm{G}_{13}$. Using cell-permeable peptide inhibitors of talin and $\mathrm{G} \alpha_{13}$ binding to the cytoplasmic tail of an integrin's $\beta$ subunit, we demonstrate that talin-mediated signaling is essential for productive infection.

Severe acute respiratory syndrome coronavirus 2 (SARS-CoV-2) is a novel virus in the Betacoronavirus genus that causes coronavirus disease 2019 (COVID-19) ${ }^{1}$. SARS-CoV-2 was first reported in Wuhan, China, and currently persists as a global pandemic ${ }^{2,3}$. SARS-CoV-2 presents similar characteristics with the original SARS-CoV in genome structure, tissue tropism, and viral pathogenesis. However, SARS-CoV-2 is more transmissible than SARS-CoV.

Cellular entry of coronaviruses depends on binding of the viral spike (S) protein to a specific cellular receptor, the angiotensin-converting enzyme $2(\mathrm{ACE} 2)^{4,5}$, and subsequent $\mathrm{S}$ protein priming by cellular protease activity such as Transmembrane Serine Protease 2 (TMPRSS2) ${ }^{6}$. Interestingly, ACE2 expression across different human tissues $^{7}$ revealed low expression of ACE2 in the lungs compared to elevated expression in the kidney and heart ${ }^{8,9}$. Nevertheless, studies have shown that type I and II interferons (IFNs) secreted during viral infection upregulate the transcription and expression of ACE2 ${ }^{10,11}$. Unlike its predecessor, SARS-Cov-2 expresses a novel K403R spike protein substitution encoding an Arginine-Glycine-Aspartic acid (RGD) motif ${ }^{12}$, introducing the potential for interacting with RGD-binding integrins, as likely mediators for viral cell entry and enhanced pathogenicity ${ }^{13}$. ACE2 contains two integrin-binding domains: an RGD motif at position 204-206 and the sequence RKKKNKAR in the cytoplasmic tail at its C-terminus ${ }^{14}$. Also, ACE2 binds integrin $\beta_{1}$ in the failing human heart ${ }^{14}$. Correlated increased expressions of $\beta_{1}{ }^{15}$ and ACE2 have been reported ${ }^{16,17}$. Others have shown that ACE2 interacts in cis with integrin $\beta_{1}$ in a manner that enhances RGD-mediated cell adhesion ${ }^{18}$.

Integrins are heterodimeric transmembrane adhesion protein receptors composed of $\alpha$ and $\beta$ subunits whose activation is tightly regulated and bidirectional ${ }^{19}$. Integrins can exist in three states characterized by their structural conformation and affinity for their ligands (Fig. 1A). The inactive, bent-closed state (BCS) with a closed headpiece has a low affinity for extracellular matrix (ECM) ligands. The bent structure inhibits the receptors from inappropriate signaling due to random binding to extracellular matrix proteins. Integrins exhibit an

\footnotetext{
${ }^{1}$ Department of Pathology, University of New Mexico School of Medicine, Albuquerque, NM 87131, USA. ${ }^{2}$ Molecular Genetics and Microbiology, University of New Mexico School of Medicine, Albuquerque, NM 87131, USA. ${ }^{3}$ Department of Internal Medicine, University of New Mexico School of Medicine, Albuquerque, NM 87131, USA. ${ }^{4}$ Center for Infectious Diseases and Immunity, University of New Mexico School of Medicine, Albuquerque, NM 87131, USA. ${ }^{5}$ Comprehensive Cancer Center, University of New Mexico Health Sciences Center, Albuquerque, NM 87131, USA. ${ }^{\bowtie}$ email: tburanda@salud.unm.edu
} 
A

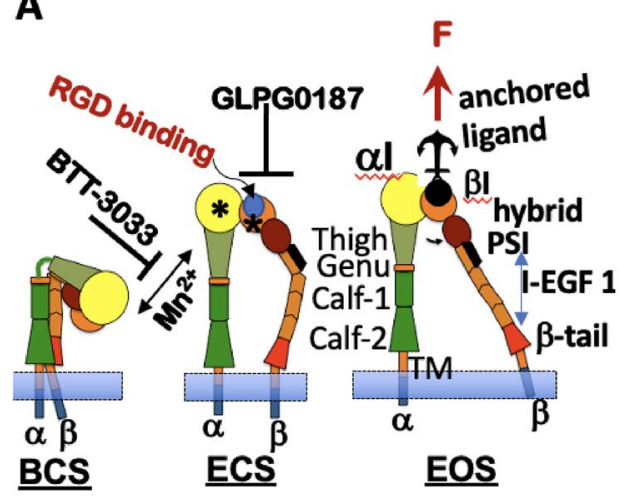

B

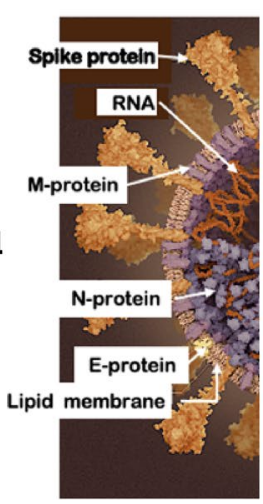

C

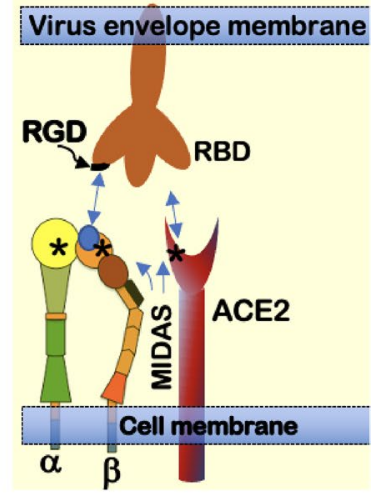

Figure 1. Integrin conformational states antagonist targets and SARS-CoV-2 binding. (A) Integrin States: First, the inactive, bent-closed state (BCS), with a closed headpiece and low affinity for extracellular matrix (ECM) ligands. The bent structure inhibits the receptors from inappropriate signaling due to random binding to extracellular matrix proteins. In the BCS form, binding to large ligands is likely limited. Second, when primed, integrins exhibit an extended-closed state (ECS) with a closed headpiece and higher ligand binding affinity than BCS. Third, active and extended-open state (EOS) with an open headpiece and maximum affinity for ECM ligands. Integrin Affinity Regulation: $\mathrm{Mn}^{2+}$ binding to the MIDAS site at the $\alpha \mathrm{I}$ and $\beta \mathrm{I}$ domain integrin induces integrin extension. $\alpha_{2} \beta_{1}$ integrin antagonist BTT 3033 binds to the $\alpha$-I domain, and stabilizes the BCS. GLP0187 blocks binding to the RGD ligand-binding domain. EOS binding to a macromolecular ligand or ECM generates a force (F) transmitted through the integrin $\beta$ subunit. (B) Model of Sars-CoV-2 virion structure (https://www. scientificamerican.com/interactive/inside-the-coronavirus/). SARS-CoV-2 are spherical or ovoid particles of sizes that span the range of 60-140 nm. The SARS-CoV-2 virion consists of a lipid bilayer envelope membrane covering a large nucleoprotein $(\mathrm{N})$-encapsidated, positive-sense RNA genome. The lipid envelope is decorated with three transmembrane proteins consisting of trimeric spike proteins (S) that project above the lipid bilayer membrane and relatively small membrane $(\mathrm{M})$ and envelope $(\mathrm{E})$ protein $\mathrm{s}^{78,79}$. S proteins bind with highaffinity $(1-50 \mathrm{nM})^{4}$ to the angiotensin-converting enzyme 2 (ACE2) for productive infection ${ }^{80}$. (C) Cartoon alignment of the receptor-binding domain (RBD) and RGD sequence on the trimeric spike protein, which favors engagement of activated integrin, adapted from ref. ${ }^{25}$ The illustrations were generated using Microsoft ${ }^{\circ}$ PowerPoint Version 16.51 (21071101).

extended-closed state (ECS) with a closed headpiece and higher ligand binding affinity than BCS when primed. Active and extended-open state (EOS) presents an open headpiece and maximum affinity for ECM ligands ${ }^{20}$. Integrin function involves coordination with cytoskeletal components whose functions regulate cell adhesion and migration ${ }^{21,22}$. Changes in integrin conformation can elicit cell-signaling events that increase ligand affinity/avidity, promote cytoskeletal rearrangement, and enable virus internalization. Ligand binding to integrins is mediated by divalent-cations bound at the Metal Ion Dependent Adhesion Site (MIDAS) domain on top of either the $\alpha \mathrm{I}$ domain, in I domain-containing integrins, or the $\beta \mathrm{I}$ domain in non- $\alpha \mathrm{I}$ integrins ${ }^{23}$. Physiologically, $1 \mathrm{mM} \mathrm{Ca}^{2+}$ and $1 \mathrm{mM} \mathrm{Mg}^{2+}$ in body fluid stabilize the BCS conformation. Under non-physiological conditions, $1 \mathrm{mM} \mathrm{Mn}^{2+}$ initiates and stabilizes ECS conformation even in the presence of $\mathrm{Ca}^{2+}$.

Many viruses use integrin-mediated endocytosis pathways for cell entry ${ }^{5,24}$. A recent bioinformatics-driven study predicted a model that placed integrins in a central ligating role, whereby SARS-CoV-2 could engage multiple receptors and form a multicomponent receptor complex and functional signaling platform ${ }^{25}$. Interestingly, ACE2 also has a similar MIDAS motif ${ }^{25}$. Still, it has not yet been established whether the ACE2 MIDAS domain has a potential role in creating synergy overlap between the ligand-binding profiles and regulation of ACE2 and integrin ${ }^{25}$. Several in vitro studies have established experimental evidence in support of cognate binding interactions between SARS-CoV-2 spike proteins, integrin $\beta_{1}{ }^{26,27}$ and integrin $\beta_{3}{ }^{12,28}$. In addition, the transmembrane glycoprotein neuropilin 1 (NRP1), which is abundantly expressed in the olfactory epithelium and promotes the endocytosis of activated $\alpha_{5} \beta_{1}$ integrin $^{29-34}$, has been recently identified as a receptor for SARS-CoV-2 infection ${ }^{34,35}$.

In this study, we took a mechanistic approach to examine the role of integrins as effectors of SARS-CoV-2 cell entry and productive infection. First, we tested whether inducing a BCS to ECS integrin conformational change with $\mathrm{Mn}^{2+24,36}$ enhanced cell binding and entry of fluorescently tagged UV-inactivated SARS-CoV-2 ${ }^{\mathrm{R} 18}$. Conversely, we used integrin extension or RGD-binding inhibitors to determine the inhibitors' effect on cellular entry. Integrins signal bidirectionally via "inside-out" and "outside-in" signaling ${ }^{22,36-41}$. Inside-out signaling is initiated by intracellular signaling upstream of talin, and other adaptor proteins binding to the integrin $\beta$-subunit cytoplasmic tail ( $\beta$-CT), which causes integrin extension (ECS) and concomitant increases in high-affinity ligand binding ${ }^{21,22}$. Integrin engagement with macromolecular ligands stimulates the transient exchange of talin for $\mathrm{Ga}_{13}$ 's occupancy of the $\beta-\mathrm{CT}^{42,43}$ which initiates integrin outside-in signaling. In the context of viral infection, integrin outside-in signaling induces cell spreading, retraction, and internalization of integrin-associated ligands. We used cell-permeable inhibitors of integrin outside-in and inside-out signaling ${ }^{42}$ to test the role of canonical 
A. SARS-CoV-2 Plaque assay

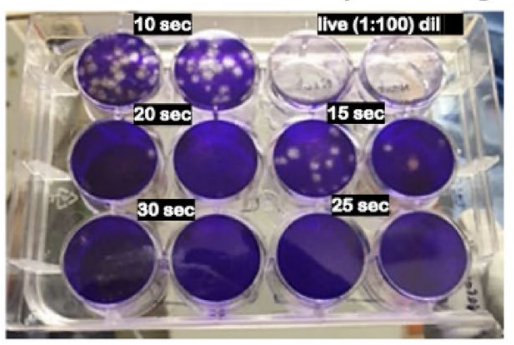

\section{B. UV Inactivation of SARS-CoV-2}

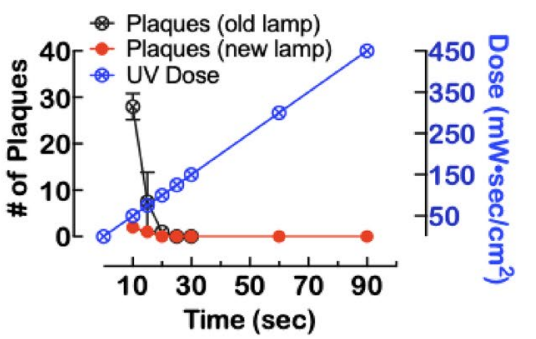

\section{Colocalization of Rab5 positive early endosomes with SARS-CoV-2 ${ }^{\text {R18 }}$}
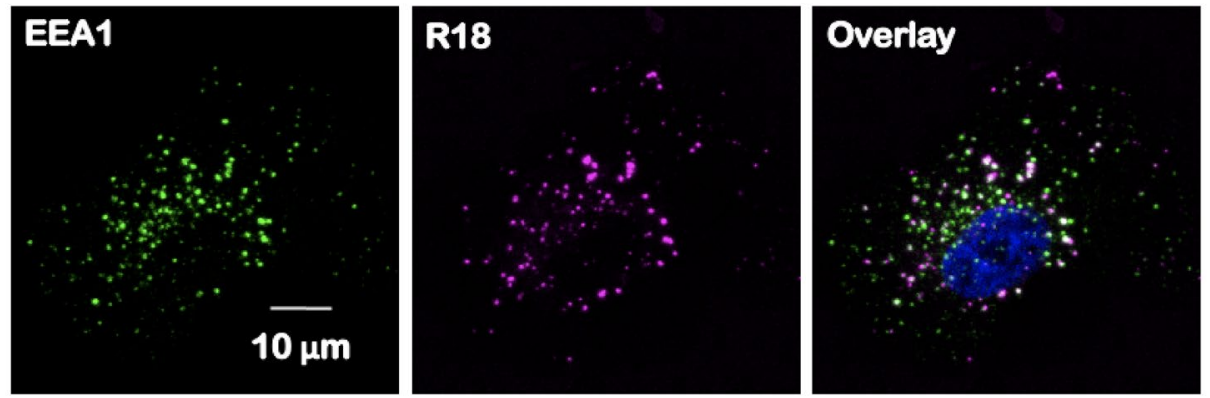

Figure 2. Characterization of UV-inactivated virus for Sars-Cov-2 studies. (A) Duplicate plaque assays of supernatants of Sars-CoV-2 exposed to increasing doses of $254 \mathrm{~nm}$ radiation and then tested for viability. The live virus completely lysed the cells at 1:100 dilution relative to UV exposed virions. (B) Graph shows UV doseresponse, leading to a significant decrease in plaque-forming units at different doses. For our experiments, a $90 \mathrm{~s}\left(450 \mathrm{~mW} \mathrm{~s} / \mathrm{cm}^{2}\right)$ UV dose was used to inactivate the virus before removal from the BSL-3 laboratory. (C) Confocal microscopy imaging of cells after incubation with SARS-CoV-2 ${ }^{\mathrm{R} 18}$ (magenta) for $15 \mathrm{~min}$, then fixed and labeled for early endosome marker, early endosome antigen 1 or EEA1 (green), an effector protein for Rab5, and nuclei (Hoechst 33,258, blue). SARS-CoV-2 ${ }^{\mathrm{R} 18}$ vesicles are trafficked to the perinuclear region, and a subset is co-localized with EEA1. Images are maximum projections and have been brightness and contrast-enhanced.

integrin signaling during cell entry of SARS-CoV-2 ${ }^{\mathrm{R} 18}$ and infectious SARS-CoV-2. Taken together, our results demonstrate that integrins play a significant role in the infectivity of SARS-CoV-2.

\section{Results}

Integrin extension promotes SARS-CoV-2 ${ }^{\text {R18 }}$ cell entry. To facilitate studies of SARS-CoV-2 hostcell entry outside of BSL-3 containment, we generated UV-inactivated virus particles. Under our experimental conditions, a minimum UV dose of $100 \mathrm{~mW} \mathrm{~s} / \mathrm{cm}^{2}$ was sufficient to completely inactivate $10^{7}$ virions/ml distributed in $500 \mu \mathrm{l}$ samples of a twelve well plate (Fig. 2A,B). UV-inactivated virus samples were fluorescently labeled with a lipophilic lipid probe, octadecyl rhodamine B (R18), intercalating the envelope membrane ${ }^{44}$. Labeled samples were purified and characterized as we have described previously for the Sin Nombre virus ${ }^{45}$.

To assess the ability of SARS-CoV-2 ${ }^{\mathrm{R} 18}$ to enter cells, we used confocal microscopy to image the relative distribution of SARS-CoV-2 $2^{\mathrm{R} 18}$ and EEA1, an effector protein for Rab5 positive early endosomes. Adherent cells were incubated on a coverslip with SARS-CoV-2R18 for $15 \mathrm{~min}$, washed, fixed, and immunolabeled for EEA1 (Fig. 2C). Internalized SARS-CoV-2 ${ }^{\mathrm{R} 18}$ was frequently found in EEA1 positive early endosomes and perinuclear space, demonstrating that the SARS-CoV-2 $2^{\mathrm{R} 18}$ internalizes and traffics as one might expect ${ }^{29-34}$. Together, these results show that UV-inactivated SARS-CoV-2 ${ }^{\mathrm{R} 18}$ is a valuable probe for investigating SARS-CoV-2 entry mechanisms.

We hypothesized that activating integrins by $\mathrm{Mn}^{2+24,36}$, which induces integrin extension and higher ligand affinity, would provide a favorable spatial orientation of the RGD-binding motifs to facilitate SARS-CoV-2 ${ }^{\text {R18 }}$ binding (Fig. 1A). Therefore, we measured initial rates $(<10 \mathrm{~min}$ binding time) of binding in activated cells $\left(\mathrm{Mn}^{2+} / \mathrm{Ca}^{2+}\right)$ relative to resting $\left(1 \mathrm{mM} \mathrm{Ca}{ }^{2+}\right.$ only). SNV-CoV-2 ${ }^{\mathrm{R} 18}$ bound to the $\mathrm{Mn}^{2+}$ activated samples at 3 times the rate of untreated cells (not shown). However, at equilibrium ( $>20 \mathrm{~min}$ incubation), the cell occupancy of SARS-CoV-2 ${ }^{\mathrm{R} 18}$ was only $\sim 20 \%$ higher in $\mathrm{Mn}^{2+}$-treated samples compared to untreated samples. As expected, the gap increased when the virus was used as a limiting reagent ${ }^{46}$. We used estimation plots ${ }^{47}$, to assess the precision of the results from multiple experiments of the integrin function assay that measured the relative binding of SARS-CoV-2 ${ }^{\mathrm{R} 18}$ to $\mathrm{Mn}^{2+}$-activated cells relative to quiescent cells on different days (Fig. 3A-D). The mean difference between the binding to $\mathrm{Mn}^{2+}$-activated and resting cells was conserved across different samples when we used at least $5000 \mathrm{SARS}-\mathrm{CoV}-2^{\mathrm{R} 18} / \mathrm{cell}$. However, when we used a lower stoichiometric ratio, e.g., 3000 SARS-CoV-2 ${ }^{\mathrm{R} 18} / \mathrm{cell}$, the gap between the site occupancy of $\mathrm{Mn}^{2+}$ activated and resting cells increased to $30 \%$, as discussed below.

To further investigate the role of integrins in SARS-CoV-2 ${ }^{\mathrm{R} 18}$ entry into Vero E6 cells, we used high binding affinity integrin antagonists: (1) BTT 3033, a selective antagonist $\left(\mathrm{EC}_{50}=130 \mathrm{nM}\right)$ of integrin $\alpha_{2} \beta_{1}$ that binds to 

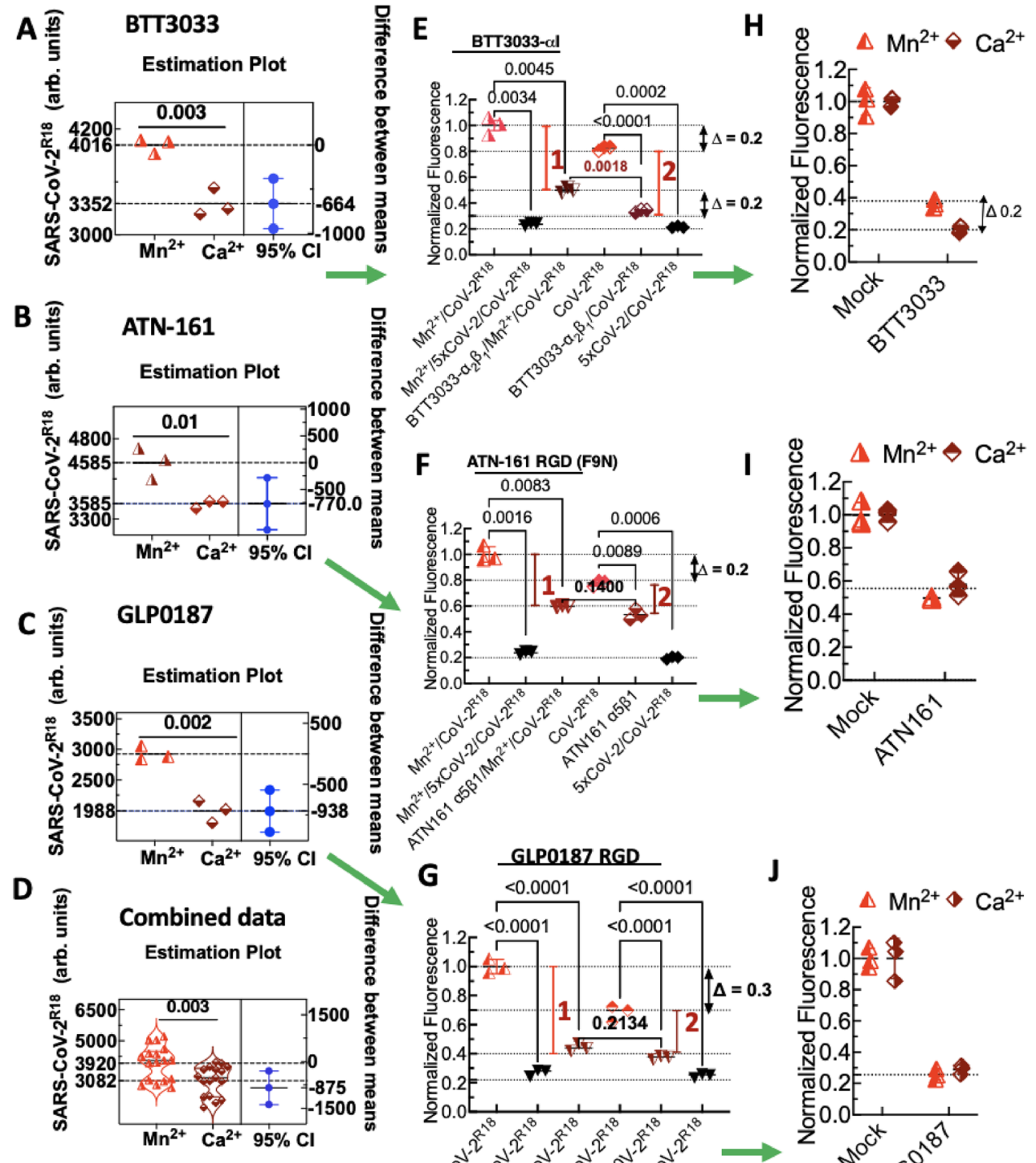

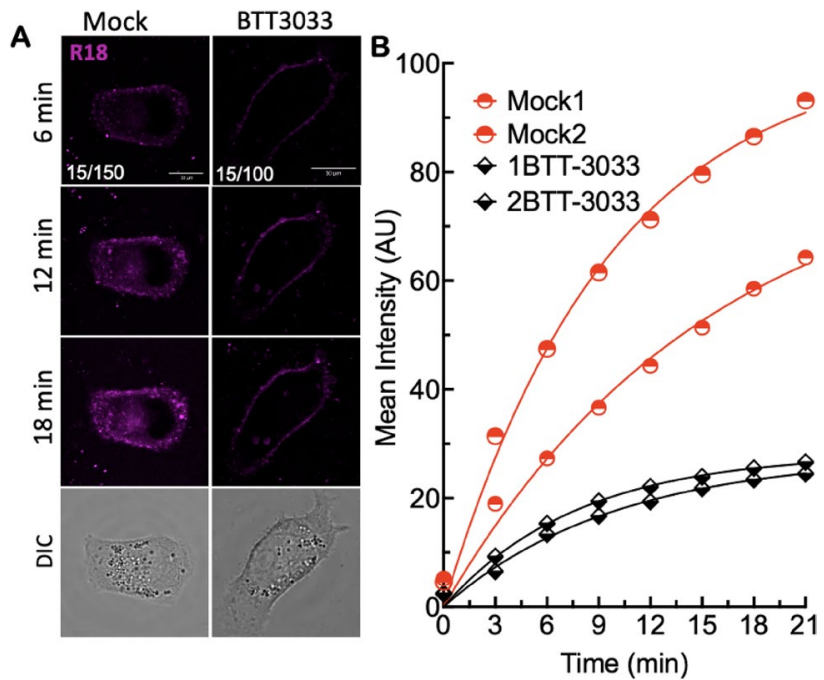

Figure 4. Stabilization of bent closed conformation with aI MIDAS domain binding integrin antagonist inhibits intracellular trafficking of SARS-CoV-2 ${ }^{\mathrm{R} 18}$. (A) Live cell imaging of SARS-CoV-2 ${ }^{\mathrm{R} 18}$ (magenta) binding and endocytosis shows perinuclear localization of SARS-CoV-2 $2^{\mathrm{R} 18}$ vesicles. At the same time, the virus is seen to accumulate at the plasma membrane when $\alpha_{2} \beta_{1}$ integrins are inhibited by $10 \mu \mathrm{M}$ BTT 3033 . Fluorescence images represent maximum projections of five confocal z slices. Mock and BTT 3033 treated samples are shown with different lookup tables (LUT) since binding in treated cells was lower than untreated cells. LUT lower/ upper values are presented in the lower-left corner of 6-min timepoint images. Scale bars, $10 \mu \mathrm{m}$. (B) Traces of absolute intensity values of virus binding over time. Two representative cells for each condition are plotted from data acquired on the same day to compare intensity values directly. Data were fit to a non-linear regression function with arbitrary constants for appearance purposes. Imaging data were repeated at least three separate times.

a site close to the $\alpha_{2}$ I MIDAS domain and stabilizes the integrin bent conformation state (BCS $)^{48}$, (2) ATN-161, a non-RGD peptide ${ }^{49}$ derived from the synergy region of fibronectin ${ }^{50}$, known to exhibit specific antagonism for $\alpha_{5} \beta_{1}$ and $\alpha_{\mathrm{II}} \beta_{3}$ and also recently shown to inhibit SARS-CoV-2 infectivity ${ }^{27}$, and (3) GLPG0187, a highaffinity, broad-spectrum $\left(\mathrm{EC}_{50}<10 \mathrm{nM}\right)$ integrin receptor antagonist of RGD integrins $\alpha_{5} \beta_{1}, \alpha_{\mathrm{v}} \beta_{3}, \alpha_{\mathrm{v}} \beta_{5}, \alpha_{\mathrm{v}} \beta_{1}$, $\alpha_{v} \beta_{6}{ }^{51}$. We used a titrated, fivefold excess of unlabeled SARS-CoV-2 relative to fluorescent SARS-CoV- $2^{\text {R18 }}$ as a control for competitive inhibition of SARS-CoV-2 ${ }^{\mathrm{R} 18}$ binding. Paired samples of cell suspensions in $\mathrm{Mn}^{2+}$-replete and $\mathrm{Mn}^{2+}$-free media were treated with the above integrin antagonists. Total viral binding was normalized to $\mathrm{Mn}^{2+}$-treated samples for each experimental condition. The graphs show that $\mathrm{Mn}^{2+}$ treatment increased SARS$\mathrm{CoV}-2^{\mathrm{R} 18}$ occupancy of cells by $20 \%$ compared to $\mathrm{Mn}^{2+}$-free conditions (Fig. $3 \mathrm{E}, \mathrm{F}$ ). As noted above, using significantly fewer SARS-CoV-2 ${ }^{\mathrm{R} 18}$ than 5000 increases the gap between binding to the $\mathrm{Mn}^{2+}$-activated and resting as indicated for the GLPG0187 sample (Fig. 3G). We also show in a subsequent experiment that raising SARS-CoV-2 ${ }^{\mathrm{R} 18}$ to a stoichiometric excess limited the site occupancy gap to $20 \%$ (Supplemental Figure 1).

The positive control for inhibition (5xCov-2 in data graphs) blocked $80 \%$ of SARS-CoV-2 ${ }^{\mathrm{R} 18}$ and equally inhibited $\mathrm{Mn}^{2+}$-treated and untreated samples. Reasoning that the residual signal of $5 \times \mathrm{Cov}-2$ treated samples was due to non-specific binding to the cell membrane, we subtracted the fluorescence of cells blocked with $5 \mathrm{xCov}-2$ and then normalized the data to mock-treated cells. Finally, we compared the relative efficacy of the inhibitors in $\mathrm{Mn}^{2+}$-replete and -free conditions of the normalized data (Fig. 3H-J). The fraction of $\mathrm{Mn}^{2+}$-activated integrins (20\%) were refractory to BTT 3033 treatment (Fig. 3H). BTT 3033 selectively binds to the BCS integrin structure ${ }^{48}$ and does not bind to $\mathrm{Mn}^{2+}$ activated integrins. In contrast, ATN-161 and GLPG0187 were agnostic to $\mathrm{Mn}^{2+}$ treated cells, as the same baseline was achieved for either condition (Fig. 3I,J). Overall, GLPG0187 (Fig. 3I) appeared to be a better competitive inhibitor of SARS-CoV-2 ${ }^{\mathrm{R} 18}$ compared to ATN-161 (Fig. 3J). The difference for the latter was potentially due to ATN-161's overall specificity for integrin $\alpha_{5} \beta_{1}$. Thus, the expression level of $\alpha_{5} \beta_{1}$, in Vero E6 cells, relative to other integrins with which $\alpha_{5} \beta_{1}$ would compete for SARS-CoV-2 ${ }^{\mathrm{R} 18}$ engagement governed its apparent efficacy. Also, ATN-161 is known to exhibit U-shaped dose-response characteristics ${ }^{49}$ thus, presenting a need to identify an optimally active-dose by titration of ATN-161 ${ }^{27}$ which is beyond the scope of our present study. The mechanistic specificity of integrin inhibition by these antagonists regarding SARS-CoV-2 uptake strongly supports the idea that (1) integrin RGD engagement is an essential co-factor for cell entry and (2) integrin extension is required for cell entry based on BTT 3033's mechanism of action.

Inhibition of integrin activation or binding to SARS-CoV-2 ${ }^{\mathrm{R} 18}$ blocks intracellular trafficking. We then used live-cell confocal microscopy to visualize Vero E6 cell entry and trafficking of SARS-CoV$2^{\mathrm{R} 18}$ in DMSO (mock)- and BTT 3033-treated cells (Fig. 4A, B). Most of the cells treated with GLPG0187 were de-adhered from the plate and were thus not suitable for imaging. The loss of cells with GLPG0187 was likely due to the loss of integrin-mediated adhesion by the broad-spectrum inhibitor. Cells were imaged at 3-min intervals for $21 \mathrm{~min}$ after the addition of $\sim 10^{7}$ SARS-CoV-2 ${ }^{\mathrm{R} 18}$ particles. In DMSO treated cells (Mock in Fig. 4), SARS- 
Figure 5. Inhibition of integrin activation blocks cell entry of SARS-CoV-2 ${ }^{\mathrm{R} 18}$, suggesting integrin-mediated signaling is required for productive infection. (A) Aligned sequences of $\beta 1$ and $\beta 3$-integrin cytoplasmic tails $(\beta-C T)$. The NPxY motif tyrosine residues (shown in brown) and the Ser and Thr residues (shown in purple) are important phosphorylation sites required for exchanging adaptor proteins. Srk family kinase-mediated phosphorylation of the NPxY motifs inhibits the binding of talin while promoting the association of inhibitor proteins such as DOK-1. Interaction zones between $\beta$-CT and adaptor proteins are denoted by associated horizontal lines. Functional roles of the proteins are indicated in parenthesis. For a detailed description, see refs. ${ }^{41,54}$. The membrane-permeable peptides $\mathrm{mP6}$ and mP13 were based on the integrin $\beta_{3}$ cytoplasmic tail. (B) Model of outside-inside-out signaling for integrin-mediated cell entry. Hypothetical SARS-CoV-2 binding to integrin $\beta_{1}$ initiates $G \alpha_{13}$ binding to the $\beta_{1}$ cytoplasmic tail, which stimulates outside-in signaling in the absence of a known receptor-stimulated GPCR mediated inside-out signaling. mP6 is a specific inhibitor of $\mathrm{Ga}_{13}$ binding to the $\beta_{1}$ cytoplasmic tail. The illustrations were generated using Microsoft PowerPoint Version 16.51 (21071101). (C) Relative fluorescence readings of suspension Vero E6 cells after 30 min incubation with SARS-CoV-2 ${ }^{\text {R18 }}$ in vehicle- and $100 \mu \mathrm{M}$ mP6 treated cells. (D) Live cell imaging of SARS-CoV-2 ${ }^{\mathrm{R} 18}$ (magenta) binding and endocytosis shows cell membrane and perinuclear localization of SARS-CoV-2 ${ }^{\mathrm{R} 18}$ vesicles. At the same time, the virus is seen to remain at the plasma membrane in cells treated with $50 \mu \mathrm{M}$ mP6. LUT ranges are shown in the bottom left corner of 6-min timepoint images. Scale bars, $10 \mu \mathrm{m}$. (E) Traces of absolute intensity values of virus binding over time. Two representative cells for each condition are plotted from data acquired on the same day to compare intensity values directly. For comparison, mock-treated cell data are the same as in Fig. 4. Data were fit to a non-linear regression function with arbitrary constants for appearance purposes. (F) Inhibition of SARS-CoV-2 productive infection. Suspension Vero E6 cells were preincubated with $250 \mu \mathrm{M}$ $\mathrm{mP6}$ and $250 \mu \mathrm{M} \mathrm{mP13}$ for $30 \mathrm{~min}$ and followed by infection with $0.01 \mathrm{MOI}$ SARS-CoV-2 for an additional $60 \mathrm{~min}$ incubation. Cells were washed twice, transferred to a 12 well plate for $48 \mathrm{~h}$, and assayed for viral RNA by RT-qPCR. Comparisons were performed using Ordinary one-way ANOVA, with Tukey's multiple comparison test using GraphPad Prism version 9.2.0.

$\mathrm{CoV}-2^{\mathrm{R} 18}$ particles were visible at cell membranes within $3 \mathrm{~min}$, subsequently developed punctate features at the cell periphery, and trafficked to the perinuclear space. The rate of cell entry (time to perinuclear space $\sim 10 \mathrm{~min}$ ) was comparable to infectious virions ${ }^{52}$. For the BTT 3033-treated cells, early peripheral membrane localization of SARS-CoV-2 $2^{\mathrm{R} 18}$ showed significant diminution of discernable puncta. It did not undergo retrograde traffic towards the perinuclear region within the timeframe of the experiment. The relative amount of virus binding to the surface was also reduced with BTT 3033 treatment (Fig. 4A,B), consistent with reduced binding observed by flow cytometry measurements (Fig. 2).

Blocking of integrin signaling significantly inhibits productive infection of cells by SARS-CoV-2. Integrin activation is a complex and well-regulated spatiotemporal process involving the synchronized assembly and disassembly of multiple signaling elements at the integrin's $\beta$-cytoplasmic tail $(\beta \text {-CT })^{53-}$ ${ }^{55}$. Various groups have described a network of up to 156 interacting components that comprise the integrin adhesome $^{56-59}$. Some adhesome components relevant to our study are shown in (Fig. 5A). Most $\beta$-CTs contain conserved sequences needed for integrin activity, such as the two $\beta$ chain NPxY/F sequences, which are sites of competitive binding by adaptor proteins that regulate integrin activation and deactivation ${ }^{41,53}$, including sorting signals for clathrin-mediated endocytosis ${ }^{60-63}$. The phosphorylatable tyrosine $(\mathrm{Y})$ residues of NPxY motifs are key regulatory sites of integrin activation on the $\beta$-CT. For example, $\mathrm{N}^{780} \mathrm{PIY}^{783}$ and $\mathrm{N}^{792} \mathrm{PKY}^{795}$ in $\beta_{1}$ and $\mathrm{N}^{744} \mathrm{PLY}^{747}$ and $\mathrm{N}^{756} \mathrm{ITY}^{759}$ in $\beta_{3}$ are motifs phosphorylated by Src family kinases (SFK) that may positively or negatively regulate interactions with phosphotyrosine-binding (PTB) domain-containing proteins. During the early stage of integrin activation, inhibitory proteins are displaced from the $\beta$-CT in exchange for integrin activators, ending with the recruitment of talin to the integrin tail ${ }^{38}$. However, the early wave of talin-mediated insideout signaling is transiently terminated to allow $\mathrm{Ga}_{13}$, the effector of outside-in signaling, to bind to the conserved ExE motif (where $x$ denotes any residue for specific integrins, e.g., EEE for $\beta_{3}$-CT and EKE for $\beta_{1}$-CT Fig. 5A), which overlaps the talin binding domain ${ }^{42}$.

Integrin binding to macromolecular ligands, such as SARS-CoV-2, facilitates $\mathrm{Ga}_{13}$-mediated outside-in signaling. Transmission of the tensile force through the integrin to talin stabilizes high-affinity integrin binding (in the EOS) to the ECM promotes the 'second wave' of inside-out signaling (Fig. 5B). The sequential mechanism of inside-out and outside-in signaling was previously established in part by the use of two myristoylated peptides, mP6 (Myr-FEEERA-OH), derived from the $\mathrm{Ga}_{13}$-binding domain and mP13 (Myr-KFEEERARAKWDT-OH) mimicking the $\beta_{3}$-CT's talin binding domain ${ }^{42}$. It is worth noting that the previous $\mathrm{mP} 6$ and mP13 related study by Shen et al. ${ }^{42}$ established that the minimal sequence of EEERA does not interact with talin and is a specific inhibitor of $\mathrm{Ga}_{13}$ association with the $\beta$-CT and had no effect on talin-dependent inside-out signaling, or the late phase of outside-in signaling associated with the second wave of talin binding. However, mP13 affects all phases of integrin signaling ${ }^{42}$. To investigate the relationship between the integrin signaling events and SARS-CoV-2 engagement and cell entry, we treated cells with mP6 peptide, which inhibited cell entry of SARS-CoV-2 ${ }^{\mathrm{R} 18}$ in flow cytometry and microscopy experiments (Fig. 5C-E). Similarly, mP13 inhibited cell entry in flow cytometry experiments (data not shown). The results for mP6 treated cells suggest that SARS-CoV-2 engagement initiates a $\mathrm{Ga}_{13}$-mediated outside-in integrin activation without a known receptor stimulus which is consistent with the idea that SARS-CoV-2 binding induces integrin activation ${ }^{64}$, as we previously demonstrated for the Sin Nombre virus $^{24}$. 

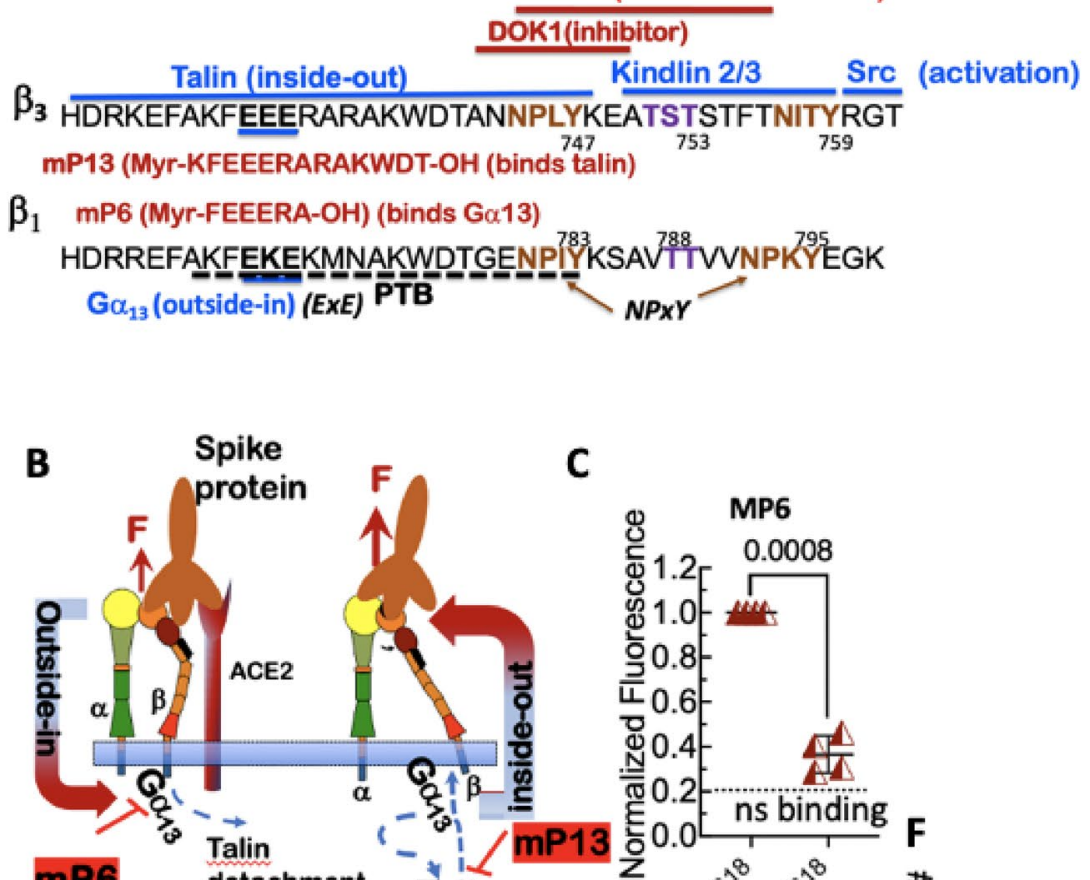

C

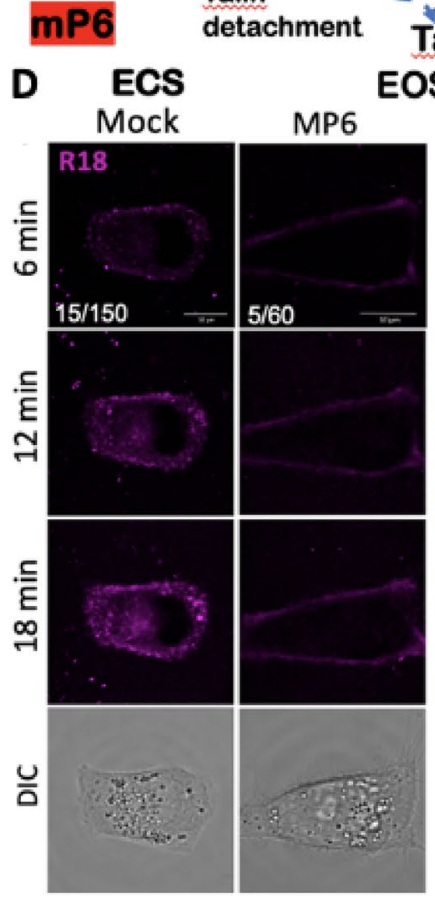

Talin
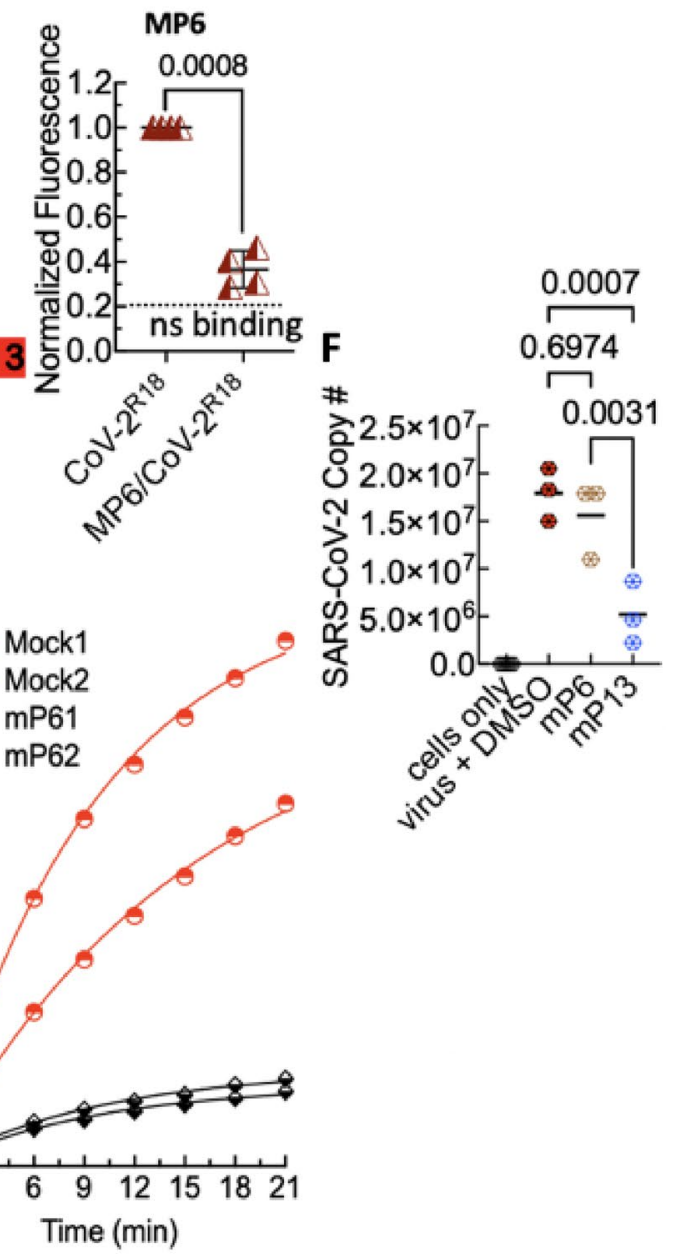

Because mP6 and mP13 are membrane-permeable peptides, they were suitable for infectivity experiments while obviating the need to expose cells to DMSO for extended periods. We, therefore, tested the efficacy of $\mathrm{mP6}$ and $\mathrm{mP} 13$ at inhibiting cell entry and productive infection in Vero E6 cells with a 0.01 multiplicity of infection (MOI) of SARS-CoV-2. For the productive infection assay, infected cells were plated at confluency $(500,000$ cells/well in a 12 well plate) to minimize cell growth for $48 \mathrm{~h}$ post-infection. We used RT-qPCR to measure viral nucleocapsid RNA in the suspended cells or intact cell monolayers at $48 \mathrm{~h}$ post-infection, respectively. At $48 \mathrm{~h}$ post-infection, inhibition of productive infection by $\mathrm{mP} 13$ was significant relative to mock-treated cells, whereas the effect of $\mathrm{mP6}$ was insignificant (Fig. 5F). The failure of $\mathrm{mP6}$ to inhibit productive infection is consistent with the notion that viral replication ${ }^{52,65}$ perturbs $\mathrm{Ca}^{2+}$ homeostasis within the infected cells ${ }^{66}$ and thus dispenses with $\mathrm{Ga}_{13}$ activity in favor of talin-induced outside in-signaling ${ }^{42}$. 


\section{Discussion}

This study provides mechanistic evidence for the functionality of extracellular ligand-binding domains of integrin $\beta_{1}$ and cytoplasmic tails of integrins in general ${ }^{25,28}$, which offer possible molecular links between ACE2 and integrins. We show that $\mathrm{Mn}^{2+}$, which induces integrin extension and high-affinity ligand binding, enhances the cell entry of SARS-CoV-2 ${ }^{\mathrm{R} 18}$. The increased virus binding and entry is consistent with the notion that integrin affinity and/or extension are essential for cell entry. In support of integrin-dependent endocytosis as a pathway of SARS-CoV-2 ${ }^{\mathrm{R} 18}$ internalization, we used broad-spectrum RGD antagonists such as GLPG0187, which inhibited cell entry regardless of integrin activation status. Our study also suggested integrin specificity. BTT 3033, an $\alpha$ I allosteric antagonist that binds to the bent closed conformation of integrin $\beta 1$ and stabilizes it, supports the possibility of integrin-dependent endocytosis of SARS-CoV- $2^{\mathrm{R} 18}$ upon receptor binding. In a different framework, our data also show that SARS-CoV-2 $2^{\mathrm{R} 18}$ can bind to low affinity and presumptively bent-conformation integrins ${ }^{23}$, however, in BTT 3033 treated cells, cell entry by SARS-CoV-2 ${ }^{\mathrm{R} 18}$ is inhibited because integrin activation post- SARS-CoV-2 $2^{\mathrm{R} 18}$ engagement is prevented. Thus, our data contextualize integrin extension as the "sine qua non of integrin cell adhesion function, ${ }^{23}$ which in turn is an essential condition for integrin-mediated cell entry by SARS-CoV-2.

Focal adhesion kinase (FAK) ${ }^{67}$ is a well-established component of the adhesome that potentially bridges the signaling gap between integrin signaling turnover ${ }^{68}$ and ACE2. FAK is a tyrosine kinase known to direct the recruitment of talin to integrin $\beta_{1}$-enriched nascent adhesions ${ }^{60,61}$. In ailing heart tissues, ACE2 binds integrin $\alpha_{5} \beta_{1}$ in an RGD-independent manner. It is known to regulate FAK mediated cell adhesion and integrin signaling ${ }^{18}$, which terminates with endosomal trafficking ${ }^{30}$ (of virion-bearing integrins). The binding of macromolecular RGD ligands to resting integrins elicits ligand-induced integrin activation ${ }^{64}$. We hypothesize that in our in vitro experiments, SARS-CoV-2 binding to inactive integrins triggers a series of spatiotemporally-regulated recruitment of adhesome components, including $\mathrm{Ga}_{13}$ and talin, to the $\beta$-CT. Our data show that talin interaction with integrin $\beta$-CTs, which causes integrin extension, is indispensable for productive infection (Fig. 5). Talin binding to the $\beta$-CT generates the requisite inside-out signal that increases the affinity of the integrin ectodomain for SARS-CoV-2 binding, which in turn increases viral load. Cell entry of SARS-CoV-2 is clathrin-dependent ${ }^{69}$. Endocytosis of integrins is clathrin-dependent and -independent ${ }^{70}$ and involves adaptor proteins such as Dab2 and $\mathrm{Numb}^{71,72}$ attached to the $\beta$-CTs NPxY/NxxY motifs (Fig. 5A). Alternatively, some integrin $\alpha$-subunits harbor a common endocytosis motif $(\mathrm{Yxx} \phi)$ recognized by the clathrin adaptor protein $2(\mathrm{AP} 2)^{68}$.

Mészáros et al. ${ }^{25}$ have used bioinformatics to predict the existence of short amino acid sequences $(\sim 3-10$ residues): short linear motifs (SLiMs), such as NPxY/Nxxy, Yxx $\phi$ in the cytoplasmic tails of ACE2 and integrins that mediate endocytosis and autophagy. Some of their theoretical predictions have been validated by experimental studies. First, Kliche et al. ${ }^{28}$ confirmed the existence of SLiMs. They extended their findings to establish a potential connection between ACE2 and integrin $\beta_{3}$ cytoplasmic tail interactions with scaffolding and adaptor proteins linked to endocytosis and autophagy. Second, SLiM sequences known to bind and activate the transmembrane glycoprotein neuropilin 1 (NRP1) were identified as potential mediators of SARS-CoV-2 endocytosis ${ }^{25}$. Interestingly, NRP1, which is abundantly expressed in the olfactory epithelium, is now declared as an effector for SARSCoV-2 infection ${ }^{34,35}$. NRP1 localizes at adhesion sites and promotes fibronectin-bound, activated $\alpha_{5} \beta_{1}$ integrin endocytosis, and directs the cargo to the perinuclear cytoplasm ${ }^{29-34}$. Studies have shown that the endocytosis of active and inactive integrins to EEA1-containing early endosomes follows distinct mechanisms involving different adaptor proteins. The inactive integrin is promptly recycled back to the plasma membrane via an ARF6and EEA1-positive compartment in a Rab4 -dependent manner ${ }^{31}$. We observed that in BTT 3033-treated cells replete with inactive $\beta_{1}$ integrins, SARS-CoV-2 ${ }^{\mathrm{R} 18}$ remained membrane-bound, whereas untreated cells displayed internalization and perinuclear localization of SARS-CoV-2 ${ }^{\mathrm{R} 18}$. This is consistent with the known trafficking of ligand-bearing integrins, including those directed by NRP1, to the perinuclear space ${ }^{29,30,32}$.

Our study has some limitations. Integrin activation is often initiated by other receptors such as G-protein coupled receptors (GPCRs), growth factors, and other integrins ${ }^{38}$. Future studies will explore the effect of receptormediated inside-out signaling, modeled under inflammatory conditions of COVID-19. In addition, the criteria for selecting specific integrins as co-factors of SARS-CoV-2 infectivity are not known and thus worthy of future investigation. Finally, the study is based on the USA-WA1/2020 SARS-CoV-2 strain. Our present study lays the groundwork for examining the activity of the various emergent SARS-CoV-2 variants.

Although several integrins types ${ }^{12,25-28}$ are believed to be co-receptors of SARS-CoV-2 infectivity, our study suggests inhibitor specificity for integrin $\beta_{1}$. This is consistent with known factors: (1) correlated increased expressions of $\beta_{1}^{15}$ and ACE2 in relevant tissues ${ }^{16,17}$, (2) cytoplasmic tail in cis interactions between ACE2 and integrin $\beta_{1}{ }^{14}$, and (3) synergy between ACE2 and integrin $\beta_{1}$ signaling that promotes RGD mediated cell adhesion ${ }^{18}$. To optimize integrin engagement, our cell-binding assays and primary infection assays were carried out in suspension such that ACE2 and integrins were not segregated by cell polarization ${ }^{73,74}$. However, our microscopy studies on adherent cells agreed with the flow cytometry results. Thus, our study represents an initial step toward establishing a mechanistic role for SARS-CoV-2-mediated integrin activation required for cell entry and productive infection.

\section{Materials and methods}

Materials. USA-WA1/2020 SARS-CoV-2 strain was obtained from BEI Resources (NIAID, NIH). Integrin inhibitors, BTT3033, a selective inhibitor of $\alpha_{2} \beta_{1}$, ATN-161 an integrin $\alpha_{5} \beta_{1}$ antagonist ${ }^{27}$, and GLPG0187 a broad-spectrum integrin inhibitor, were purchased as powders from Tocris Bioscience. The EEA1 rabbit monoclonal antibody (clone C45B10) was from Cell Signaling Technologies (CAT\# 3288S). Alexa fluor 647 conjugated $\mathrm{F}(\mathrm{ab}) 2$ fragment goat anti-rabbit IgG was from Invitrogen (CAT\# A21246). In addition, myristoylated peptides; mP6 (Myr-FEEERA-OH) and mP13 (Myr-KFEEERARAKWDT-OH) were custom synthesized at Vivitide. 
Cell culture. African green monkey kidney cells (Vero E6, ATCC) were maintained in DMEM media from Sigma CAT\# D5796. All media contained 10\% heat-inactivated fetal bovine serum (FBS), $100 \mathrm{U} / \mathrm{ml}$ penicillin, $100 \mu \mathrm{g} / \mathrm{ml}$ streptomycin, and $2 \mathrm{mM} \mathrm{L}$-glutamine and were kept at $37^{\circ} \mathrm{C}$ in a $\mathrm{CO}_{2}$ water-jacketed incubator of $5 \%$ $\mathrm{CO}_{2}$ and 95\% air (Forma Scientific, Marietta, OH, USA).

UV inactivation and fluorescent labeling of the envelope membrane of SARS-CoV-2 with octadecyl rhodamine (R18). USA-WA1/2020 SARS-CoV-2 strain (from BEI Resources, NIAID, NIH) was cultured in Vero E6 cells in a biosafety level 3 (BSL-3) containment under a protocol approved by the University of New Mexico's Institutional Biosafety Committee or IBC (Public Health Service registration number C200410180267). First, live SARS-CoV-2 were harvested at peak titers of $10^{7}$ plaque-forming units $/ \mathrm{mL}$ (PFU/ml). Next, SARS-CoV-2 was UV inactivated using $254 \mathrm{~nm}\left(\approx 5 \mathrm{~mW} / \mathrm{cm}^{2}\right)$ U.V. irradiation of a TS-254R Spectroline UV Transilluminator (Spectronics Corp., Westbury, NY) following a similar protocol for inactivating pathogenic orthohantaviruses ${ }^{45,75}$. Briefly, Vero E6 cells were inoculated with SARS-CoV-2 and maintained at $37^{\circ} \mathrm{C}$ for 2-4 days. At 70-75\% cell death (due to viral cytopathic effect), the supernatant was harvested and subjected to light centrifugation ( $1000 \mathrm{rpm}, 10 \mathrm{~min}$ ) to remove cellular debris. For UV inactivation, supernatants were added to a 12 well plate at $500 \mu \mathrm{l}$ aliquot/well. Then UV -irradiated at $3.8 \mathrm{~cm}$ above the sample for $0,10,15,20,25,30$, 60 , and $90 \mathrm{~s}$ and then tested for viability by a 3-day plaque assay as described elsewhere ${ }^{76,77}$. The titration of UV irradiation times was used to establish a minimal UV dose for complete inactivation. After UV treatment, the $500 \mu \mathrm{l}$ fractions were pooled into $15 \mathrm{~mL}$ tubes stored in a $-80^{\circ} \mathrm{C}$ freezer pending the results of a plaque assay. Under our experimental conditions, we established that a minimum UV irradiation interval of $25 \mathrm{~s}$ was required for the complete inactivation of SARS-CoV-2. A $90 \mathrm{~s}$ UV dose was approved by the IBC for removal of inactivated SARS-CoV-2 out of the BSL-3 lab after it was established that the virus particles were capable of specific binding to Vero E6 cells.

Crude UV-inactivated SARS-CoV-2 samples were purified by floating $10 \mathrm{ml}$ of SARS-CoV-2 supernatant on a density gradient comprising $2 \mathrm{ml}$ volumes of $1.2 \mathrm{~g} / \mathrm{ml}$ and $1.0 \mathrm{~g} / \mathrm{ml} \mathrm{CsCl}$ in PBS media in $14 \times 89-\mathrm{mm}$ Beckman polyallomer tubes. The samples were centrifuged for $1.5 \mathrm{~h}$ at $4{ }^{\circ} \mathrm{C}$ using a Beckman SW41Ti rotor at 30,000 pm. A band was collected at the interface and purified by centrifugation in HHB using $100 \mathrm{kDa}$ cutoff Microcon Centrifugal Filter. The purified SARS-CoV-2 samples were stored in $1.0 \mathrm{ml}$ aliquots at $-80{ }^{\circ} \mathrm{C}$. SARS-CoV-2 particles were fluorescently labeled and calibrated according to the same protocol used for the Sin Nombre virus $(\mathrm{SNV})^{45}$. The final volume for each labeled batch preparation was limited to $500 \mu$ l. The number of SARS-CoV$2^{\mathrm{R} 18}$ particles in each sample preparation was estimated from absorption measurements using the following equation: \# of moles of R18 (derived from sample absorbance) $\times$ Avogadro's number $\left(6.02 \times 10^{23}\right.$ molecules mole $\left.^{-1}\right) /$ estimated average number of R18 molecules per virion $(10,000)^{45}$. The yield of SARS-CoV-2 $2^{\mathrm{R} 18}$ particles was typically in the $10^{8} / \mu \mathrm{l}$ range. Batch samples were stored in $20 \mu \mathrm{l}$ aliquots at $-80^{\circ} \mathrm{C}$.

Flow cytometry binding assays of SARS-CoV-2 ${ }^{\mathrm{R} 18}$ to vero E6 cells. For flow cytometry assays, cells were cultured in T25 or T75 flasks to $80 \%$ confluence. Cells were then treated with $0.25 \%$ trypsin and transferred to minimum essential medium (MEM) media. Cell counts and viability were performed using a Life Technologies Countess II FL Automated cell counter (Thermofisher Scientific). Test suspension cell samples were transferred to microfuge tubes in $40 \mu \mathrm{l}$-aliquots $(1000 \mathrm{cells} / \mu \mathrm{l})$. SARS-CoV- $2^{\mathrm{R} 18}$ was added to tubes at 5000 SARS-CoV- $2^{\mathrm{R} 18} / \mathrm{cell}$ and incubated using a shaker at $500 \mathrm{rpm}$ for $20 \mathrm{~min}$ at $37^{\circ} \mathrm{C}$. For blocking assays, cells were incubated with $5 \times$ unlabeled SARS-CoV- 2 or $10 \mu \mathrm{M}$ integrin inhibitors for $20 \mathrm{~min}$ before the addition of SARS$\mathrm{CoV}-2^{\mathrm{R} 18}$. Samples were centrifuged at $3,000 \mathrm{rpm}$; the pellet was resuspended in HHB buffer (30 mM HEPES, $110 \mathrm{mM} \mathrm{NaCl}, 10 \mathrm{mM} \mathrm{KCl}, 1 \mathrm{mM} \mathrm{MgCl}{ }_{2} \cdot 6 \mathrm{H}_{2} \mathrm{O}$, and $10 \mathrm{mM}$ glucose, $\mathrm{pH}$ 7.4) buffer and read on an Accuri flow cytometer. For kinetic assays, Vero E6 suspension cells in $40 \mu \mathrm{l}$ volumes $(1000$ cells/ $\mu \mathrm{l})$ were placed in $\pm \mathrm{Mn}^{2+}$ media in duplicate microfuge tubes at $37^{\circ} \mathrm{C}$. Sars-CoV-2 $2^{\mathrm{R} 18}$ was then added (5000 virions/cell) to the tubes and incubated for 1, 3, 5, 7, 9 min. At each time point, the tubes were quenched in an ice bath, then samples were centrifuged and resuspended in $95 \mu \mathrm{lHB}$ buffer and analyzed on a flow cytometer.

Live cell confocal microscopy. Imaging was performed using a Leica TCS SP8 Laser Scanning Confocal Microscope with a $63 \times$ water objective and a Bioptechs objective heater to maintain cells at physiological temperature $\left(\sim 36-37^{\circ} \mathrm{C}\right)$. Vero E6 cells were plated in eight-well Lab-Tek (Nunc) chambers at a density of 30,000 cells per well $24 \mathrm{~h}$ before imaging. Cells were imaged in Tyrode's buffer $(135 \mathrm{mM} \mathrm{NaCl}, 10 \mathrm{mM} \mathrm{KCl}, 0.4 \mathrm{mM}$ $\mathrm{MgCl}_{2}, 1 \mathrm{mM} \mathrm{CaCl} 220 \mathrm{mM}$ glucose, $0.1 \% \mathrm{BSA}, 10 \mathrm{mM}$ HEPES, $\mathrm{pH}$ 7.2). For integrin inhibition, cells were treated with $10 \mu \mathrm{M}$ BTT3033- $\alpha_{2} \beta_{1}$ or $50 \mu \mathrm{M}$ MP6 in Tyrode's buffer for 30 min before imaging. $~ 1 \times 10^{9}$ SARSCoV-2 ${ }^{\mathrm{R} 18}$ particles were added per well, and z-stacks ( $300 \mathrm{~nm}$ thickness) were acquired every 3 min for $21 \mathrm{~min}$ to visualize viral cell entry. R18 was excited using $561 \mathrm{~nm}$ light, isolated from the white light source. R18 emission and differential interference contrast (DIC) transmitted light were captured with Leica Hybrid detectors (HyD) in a spectral window of 571-636 nm (for R18 emission). Analysis of the accumulation of SARS-CoV-2 ${ }^{\mathrm{R} 18}$ particles in Vero E6 cells was completed using Matlab. Briefly, regions of interest (ROI) were created around the cell membrane, and the mean SARS-CoV-2 ${ }^{\mathrm{R} 18}$ intensity was measured within the cell mask at each time point.

Immunofluorescence. Vero E6 cells were plated on 18-mm coverslips overnight in a 6 well plate at a density of 100,000 cells/well. Cells were exposed to $\sim 1 \times 10^{9} \mathrm{SARS}-\mathrm{CoV}-2^{\mathrm{R} 18}$ particles/well for $15 \mathrm{~min}$ at $37^{\circ} \mathrm{C}$, in the presence or absence of $10 \mu \mathrm{M}$ BTT 3033. Cells were then washed in phosphate-buffered saline (PBS) and fixed using 4\% paraformaldehyde (PFA) in PBS for $15 \mathrm{~min}$ at room temperature. Cells were extensively washed with $10 \mathrm{mM}$ Tris (pH 7.4) and PBS and permeabilized with $0.1 \%$ Triton. Cells were labeled with anti-EEA1 primary antibody and anti-rabbit Alexa Fluor 647 secondary. Nuclei were stained with Hoechst 33258. Cells were 
mounted on microscope slides using Prolong Diamond Antifade Mountant (Invitrogen, CAT\#P33970). Samples were imaged using a Leica TCS SP8 Laser Scanning Confocal Microscope with a $63 \times$ oil objective.

Infection inhibition. Vero E6 cells grown at 80\% confluency were trypsinized and divided into microfuge tubes aliquots of $1.5 \times 10^{6}$ cells in $750 \mu \mathrm{l}$ media containing $250 \mu \mathrm{M} \mathrm{mP6}, 250 \mu \mathrm{M} \mathrm{mP13}, 10 \mu \mathrm{M}$ BTT 3033, DMSO, and media only. Samples were shaken at $500 \mathrm{rpm}$ for $30 \mathrm{~min}$ at $37^{\circ} \mathrm{C}$. After transfer to a BSL-3 laboratory, 0.01 MOI of SARS CoV-2 (lot \#P3: $1.2 \times 10^{7} \mathrm{pfu}$ ) and then incubated for 60 min while shaking. Tubes were spun down (1000 rpm for $3 \mathrm{~min}$ ), resuspended in fresh media, and spun down again. The cells were then resuspended in $300 \mu \mathrm{l}$ of media and transferred to a 12 well plate in $100 \mu \mathrm{l}$ aliquots (500,000 virions/well) for triplicate measurements. An additional $400 \mu \mathrm{l}$ were added to each well for a final volume of $500 \mu$ l. The plate was transferred to an incubator for $48 \mathrm{~h}$ to allow the virus to replicate. The cells were then washed with 1xPBS before RNA was extracted with TRIzol ${ }^{\mathrm{m}}$ (Thermofisher, \#15596026) according to the manufacturer's protocol:

(https://assets.thermofisher.com/TFS-Assets/LSG/manuals/trizol_reagent.pdf).

The RNA was quantified with a Nanodrop and total cellular cDNA transcribed with the Applied Biosystems ${ }^{\mathrm{Tm}}$ High-Capacity cDNA Reverse Transcription Kit (Fisher Scientific \#43-688-14).

RT-qPCR was performed with the TaqMan Fast Advance Master Mix (Fisher Scientific \#4444963) and the following primers ordered from Integrated DNA Technologies: Forward: 5'-CCCTGTGGGTTTTACACTTAA3', Reverse: 5'-ACGATTGTGCATCAGCTGA-3', and probe: 5'-[FAM] CCGTCTGCGGTATGTGGAAAGGTT ATGG [BHQ1]-3'. The RT-qPCR was performed using an Applied Biosystems QuantStudio 5 instrument.

Statistical analysis. SARS-CoV-2 ${ }^{\mathrm{R} 18}$ binding was expressed as the mean channel fluorescence (MCF) output of the flow cytometer. For different batch preparations of SARS-CoV-2 ${ }^{\mathrm{R} 18}$, we first tested functional binding of SARS-CoV-2 $2^{\mathrm{R} 18}$ to cells by comparing the MCF readings of $1 \mathrm{mM} \mathrm{Mn}{ }^{2+}$ - activated cells and resting cells after correcting for autofluorescence. Then, assuming sampling from a Gaussian distribution, the two groups were compared using estimation plots ${ }^{47}$ with unpaired two-tailed $t$-tests to check for consistency between batch preparations of SARS-CoV-2 ${ }^{\mathrm{R} 18}$. For integrin activation inhibitor tests involving three or more groups, comparisons were performed using Ordinary one-way ANOVA with Tukey's multiple comparison test. Data analysis was done with GraphPad Prism software version 9.2.0. Statistical significance was defined as $p<0.05$.

Received: 23 July 2021; Accepted: 30 September 2021

Published online: 14 October 2021

\section{References}

1. WHO https://www.who.int/emergencies/diseases/novel-coronavirus-2019/technical-guidance/naming-the-coronavirus-disea se-(covid-2019)-and-the-virus-that-causes-it (2020).

2. Zhou, F. et al. Clinical course and risk factors for mortality of adult inpatients with COVID-19 in Wuhan, China: A retrospective cohort study. Lancet 395, 1054-1062 (2020).

3. Chen, N. et al. Epidemiological and clinical characteristics of 99 cases of 2019 novel coronavirus pneumonia in Wuhan, China: A descriptive study. Lancet 395, 507-513 (2020).

4. Wrapp, D. et al. Cryo-EM structure of the 2019-nCoV spike in the prefusion conformation. Science 367, 1260-1263 (2020).

5. Stewart, P. L. \& Nemerow, G. R. Cell integrins: Commonly used receptors for diverse viral pathogens. Trends Microbiol. 15, 500-507 (2007).

6. Hoffmann, M. et al. SARS-CoV-2 cell entry depends on ACE2 and TMPRSS2 and is blocked by a clinically proven protease inhibitor. Cell 181, 271-280.e278 (2020).

7. Sungnak, W. et al. SARS-CoV-2 entry factors are highly expressed in nasal epithelial cells together with innate immune genes. Nat. Med. 26, 681-687 (2020).

8. Li, M. Y., Li, L., Zhang, Y. \& Wang, X. S. Expression of the SARS-CoV-2 cell receptor gene ACE2 in a wide variety of human tissues. Infect. Dis. Poverty 9, 45 (2020).

9. Hikmet, F. et al. The protein expression profile of ACE2 in human tissues. Mol. Syst. Biol. 16, e9610 (2020).

10. Harrison, A. G., Lin, T. \& Wang, P. Mechanisms of SARS-CoV-2 transmission and pathogenesis. Trends Immunol. 41, 1100-1115 (2020).

11. Ziegler, C. G. K. et al. SARS-CoV-2 receptor ACE2 is an interferon-stimulated gene in human airway epithelial cells and is detected in specific cell subsets across tissues. Cell 181, 1016-1035.e1019 (2020).

12. Nader, D., Fletcher, N., Curley, G. F. \& Kerrigan, S. W. SARS-CoV-2 uses major endothelial integrin alphavbeta3 to cause vascular dysregulation in-vitro during COVID-19. PLoS ONE 16, e0253347 (2021).

13. Makowski, L., Olson-Sidford, W. \& Weisel, J. W. Biological and clinical consequences of integrin binding via a rogue RGD motif in the SARS CoV-2 spike protein. Viruses 13, 146 (2021).

14. Lin, Q., Keller, R. S., Weaver, B. \& Zisman, L. S. Interaction of ACE2 and integrin beta1 in failing human heart. Biochem. Biophys. Acta. 1689, 175-178 (2004).

15. Sun, M. et al. Temporal response and localization of integrins betal and beta3 in the heart after myocardial infarction: Regulation by cytokines. Circulation 107, 1046-1052 (2003).

16. Krishnamurthy, P., Subramanian, V., Singh, M. \& Singh, K. Deficiency of betal integrins results in increased myocardial dysfunction after myocardial infarction. Heart 92, 1309-1315 (2006).

17. Kuba, K., Imai, Y., Ohto-Nakanishi, T. \& Penninger, J. M. Trilogy of ACE2: A peptidase in the renin-angiotensin system, a SARS receptor, and a partner for amino acid transporters. Pharmacol. Ther. 128, 119-128 (2010).

18. Clarke, N. E., Fisher, M. J., Porter, K. E., Lambert, D. W. \& Turner, A. J. Angiotensin converting enzyme (ACE) and ACE2 bind integrins and ACE2 regulates integrin signalling. PLoS ONE 7, e34747 (2012).

19. Luo, B. H. \& Springer, T. A. Integrin structures and conformational signaling. Curr. Opin. Cell Biol. 18, 579-586 (2006).

20. Luo, B. H., Carman, C. V. \& Springer, T. A. Structural basis of integrin regulation and signaling. Annu. Rev. Immunol. 25, 619-647 (2007). 
21. Nordenfelt, P., Elliott, H. L. \& Springer, T. A. Coordinated integrin activation by actin-dependent force during T-cell migration. Nat. Commun. 7, 13119 (2016).

22. Schurpf, T. \& Springer, T. A. Regulation of integrin affinity on cell surfaces. EMBO J. 30, 4712-4727 (2011).

23. Moore, T. I., Aaron, J., Chew, T. L. \& Springer, T. A. Measuring integrin conformational change on the cell surface with superresolution microscopy. Cell Rep. 22, 1903-1912 (2018).

24. Bondu, V. et al. Low-affinity binding in cis to P2Y2R mediates force-dependent integrin activation during hantavirus infection. Mol. Biol. Cell 28, 2887-2903 (2017).

25. Mészáros, B. et al. Short linear motif candidates in the cell entry system used by SARS-CoV-2 and their potential therapeutic implications. Sci. Signal. 14, eabd0334 (2021).

26. Park, E. J. et al. The spike glycoprotein of SARS-CoV-2 binds to betal integrins expressed on the surface of lung epithelial cells. Viruses 13, 645 (2021)

27. Beddingfield, B. J. et al. The integrin binding peptide, ATN-161, as a novel therapy for SARS-CoV-2 infection. JACC Basic Transl. Sci. 6, 1-8 (2021).

28. Kliche, J., Kuss, H., Ali, M. A. \& Ivarsson, Y. Cytoplasmic short linear motifs in ACE2 and integrin $\beta 3$ link SARS-CoV-2 host cell receptors to mediators of endocytosis and autophagy. Sci. Signal. 14, eabf1117 (2021).

29. Valdembri, D. et al. Neuropilin-1/GIPC1 signaling regulates alpha5betal integrin traffic and function in endothelial cells. PLoS Biol. 7, e25 (2009).

30. Mana, G., Valdembri, D. \& Serini, G. Conformationally active integrin endocytosis and traffic: Why, where, when and how?. Biochem. Soc. Trans. 48, 83-93 (2020).

31. Arjonen, A., Alanko, J., Veltel, S. \& Ivaska, J. Distinct recycling of active and inactive betal integrins. Traffic 13, 610-625 (2012).

32. De Franceschi, N., Hamidi, H., Alanko, J., Sahgal, P. \& Ivaska, J. Integrin traffic-The update. J. Cell Sci. 128, 839-852 (2015).

33. Lobert, V. H. \& Stenmark, H. The ESCRT machinery mediates polarization of fibroblasts through regulation of myosin light chain. J. Cell Sci. 125, 29-36 (2012).

34. Cantuti-Castelvetri, L. et al. Neuropilin-1 facilitates SARS-CoV-2 cell entry and infectivity. Science 370, 856-860 (2020).

35. Daly, J. L. et al. Neuropilin-1 is a host factor for SARS-CoV-2 infection. Science 370, 861-865 (2020).

36. Ye, F., Kim, C. \& Ginsberg, M. H. Reconstruction of integrin activation. Blood 119, 26-33 (2012).

37. Banno, A. \& Ginsberg, M. H. Integrin activation. Biochem. Soc. Trans. 36, 229-234 (2008).

38. Kim, C., Ye, F. \& Ginsberg, M. H. Regulation of integrin activation. Annu. Rev. Cell Dev. Biol. 27, 321-345 (2011).

39. Zhu, J., Zhu, J. \& Springer, T. A. Complete integrin headpiece opening in eight steps. J. Cell Biol. 201, 1053-1068 (2013).

40. Shen, B., Delaney, M. K. \& Du, X. Inside-out, outside-in, and inside-outside-in: G protein signaling in integrin-mediated cell adhesion, spreading, and retraction. Curr. Opin. Cell Biol. 24, 600-606 (2012).

41. Gahmberg, C. G. et al. Regulation of integrin activity and signalling. Biochem. Biophys. Acta. 1790, 431-444 (2009).

42. Shen, B. et al. A directional switch of integrin signalling and a new anti-thrombotic strategy. Nature 503, 131-135 (2013).

43. Gong, H. et al. G protein subunit Galpha13 binds to integrin alphaIIbbeta3 and mediates integrin "outside-in" signaling. Science 327, 340-343 (2010).

44. Buranda, T., Wu, Y., Perez, D., Chigaev, A. \& Sklar, L. A. Real-time partitioning of octadecyl rhodamine B into bead-supported lipid bilayer membranes revealing quantitative differences in saturable binding sites in DOPC and 1:1:1 DOPC/SM/cholesterol membranes. J. Phys. Chem. 114, 1336-1349 (2010).

45. Buranda, T. et al. Recognition of decay accelerating factor and alpha(v)beta(3) by inactivated hantaviruses: Toward the development of high-throughput screening flow cytometry assays. Anal. Biochem. 402, 151-160 (2010).

46. Benson, S. W. Foundations of Chemical Kinetics (McGraw-Hill, 1960).

47. Ho, J., Tumkaya, T., Aryal, S., Choi, H. \& Claridge-Chang, A. Moving beyond P values: Data analysis with estimation graphics. Nat. Methods 16, 565-566 (2019).

48. Nissinen, L. et al. Novel alpha2beta1 integrin inhibitors reveal that integrin binding to collagen under shear stress conditions does not require receptor preactivation. J. Biol. Chem. 287, 44694-44702 (2012).

49. Donate, F. et al. Pharmacology of the novel antiangiogenic peptide ATN-161 (Ac-PHSCN-NH2): Observation of a U-shaped dose-response curve in several preclinical models of angiogenesis and tumor growth. Clin. Cancer Res. 14, 2137-2144 (2008).

50. Benito-Jardon, M. et al. The fibronectin synergy site re-enforces cell adhesion and mediates a crosstalk between integrin classes. Elife 6, e22264 (2017).

51. Cirkel, G. A. et al. A dose escalating phase I study of GLPG0187, a broad spectrum integrin receptor antagonist, in adult patients with progressive high-grade glioma and other advanced solid malignancies. Investig. New Drugs 34, 184-192 (2016).

52. Bar-On, Y. M., Flamholz, A., Phillips, R. \& Milo, R. SARS-CoV-2 (COVID-19) by the numbers. Elife 9, e57309 (2020).

53. Goult, B. T., Yan, J. \& Schwartz, M. A. Talin as a mechanosensitive signaling hub. J. Cell Biol. 217, 3776-3784 (2018).

54. Morse, E. M., Brahme, N. N. \& Calderwood, D. A. Integrin cytoplasmic tail interactions. Biochemistry 53, 810-820 (2014).

55. Anthis, N. J. \& Campbell, I. D. The tail of integrin activation. Trends Biochem. Sci. 36, 191-198 (2011).

56. Zaidel-Bar, R. \& Geiger, B. The switchable integrin adhesome. J. Cell Sci. 123, 1385-1388 (2010).

57. Geiger, T. \& Zaidel-Bar, R. Opening the floodgates: Proteomics and the integrin adhesome. Curr. Opin. Cell Biol. 24, 562-568 (2012).

58. Ye, F., Lagarrigue, F. \& Ginsberg, M. H. SnapShot: Talin and the modular nature of the integrin adhesome. Cell 156, 1340.e1341 (2014).

59. Horton, E. R. et al. The integrin adhesome network at a glance. J. Cell Sci. 129, 4159-4163 (2016).

60. Lawson, C. et al. FAK promotes recruitment of talin to nascent adhesions to control cell motility. J. Cell Biol. 196, 223-232 (2012).

61. Nader, G. P., Ezratty, E. J. \& Gundersen, G. G. FAK, talin and PIPKIgamma regulate endocytosed integrin activation to polarize focal adhesion assembly. Nat. Cell Biol. 18, 491-503 (2016).

62. Ohno, H. et al. Interaction of tyrosine-based sorting signals with clathrin-associated proteins. Science 269, 1872-1875 (1995).

63. Maginnis, M. S. et al. NPXY motifs in the betal integrin cytoplasmic tail are required for functional reovirus entry. J. Virol. 82, 3181-3191 (2008).

64. Du, X. P. et al. Ligands "activate" integrin alpha IIb beta 3 (platelet GPIIb-IIIa). Cell 65, 409-416 (1991).

65. Ogando, N. S. et al. SARS-coronavirus-2 replication in Vero E6 cells: Replication kinetics, rapid adaptation and cytopathology. J. Gen. Virol. 101, 925-940 (2020).

66. Zhou, Y., Frey, T. K. \& Yang, J. J. Viral calciomics: Interplays between $\mathrm{Ca}^{2+}$ and virus. Cell Calcium 46, 1-17 (2009).

67. Mitra, S. K., Hanson, D. A. \& Schlaepfer, D. D. Focal adhesion kinase: In command and control of cell motility. Nat. Rev. Mol. Cell Biol. 6, 56-68 (2005).

68. Moreno-Layseca, P., Icha, J., Hamidi, H. \& Ivaska, J. Integrin trafficking in cells and tissues. Nat. Cell Biol. 21, 122-132 (2019).

69. Bayati, A., Kumar, R., Francis, V. \& McPherson, P. S. SARS-CoV-2 infects cells after viral entry via clathrin-mediated endocytosis. J. Biol. Chem. 296, 100306 (2021).

70. Ezratty, E. J., Bertaux, C., Marcantonio, E. E. \& Gundersen, G. G. Clathrin mediates integrin endocytosis for focal adhesion disassembly in migrating cells. J. Cell Biol. 187, 733-747 (2009).

71. Nishimura, T. \& Kaibuchi, K. Numb controls integrin endocytosis for directional cell migration with aPKC and PAR-3. Dev. Cell 13, 15-28 (2007) 
72. Calderwood, D. A. et al. Integrin beta cytoplasmic domain interactions with phosphotyrosine-binding domains: A structural prototype for diversity in integrin signaling. Proc. Natl. Acad. Sci. USA. 100, 2272-2277 (2003).

73. Ren, X. et al. Analysis of ACE2 in polarized epithelial cells: Surface expression and function as receptor for severe acute respiratory syndrome-associated coronavirus. J. Gen. Virol. 87, 1691-1695 (2006).

74. Drubin, D. G. \& Nelson, W. J. Origins of cell polarity. Cell 84, 335-344 (1996).

75. Buranda, T. et al. Equilibrium and kinetics of sin nombre hantavirus binding at DAF/CD55 functionalized bead surfaces. Viruses 6, 1091-1111 (2014).

76. Darnell, M. E., Subbarao, K., Feinstone, S. M. \& Taylor, D. R. Inactivation of the coronavirus that induces severe acute respiratory syndrome, SARS-CoV. J. Virol. Methods 121, 85-91 (2004).

77. Darnell, M. E. \& Taylor, D. R. Evaluation of inactivation methods for severe acute respiratory syndrome coronavirus in noncellular blood products. Transfusion 46, 1770-1777 (2006).

78. Ke, Z. et al. Structures and distributions of SARS-CoV-2 spike proteins on intact virions. Nature 588, 498-502 (2020).

79. Neuman, B. W. \& Buchmeier, M. J. Supramolecular architecture of the coronavirus particle. Adv. Virus Res. 96, 1-27 (2016).

80. Walls, A. C. et al. Structure, function, and antigenicity of the SARS-CoV-2 spike glycoprotein. Cell 183, 1735 (2020).

\section{Acknowledgements}

This project is supported by an award from the National Center for Advancing Translational Sciences, National Institutes of Health under grant number UL1TR001449, NIH R35GM-126934 (DSL). Fluorescence microscopy was performed in the University of New Mexico Comprehensive Cancer Center fluorescence microscopy shared resource (NIH P30CA118100).

\section{Author contributions}

T.B. conceived and designed the project. T.B., D.S.L. conceived the flow cytometry and microscopy experiments, respectively; A.M.K. and S.B. provided essential materials; P.S., T.B., V.B., D.A.R., A.M.K., S.B., and D.S.L. carried out the experiments; all authors reviewed the manuscript.

\section{Competing interests}

The authors declare no competing interests.

\section{Additional information}

Supplementary Information The online version contains supplementary material available at https://doi.org/ 10.1038/s41598-021-99893-7.

Correspondence and requests for materials should be addressed to T.B.

Reprints and permissions information is available at www.nature.com/reprints.

Publisher's note Springer Nature remains neutral with regard to jurisdictional claims in published maps and institutional affiliations.

(c) (i) Open Access This article is licensed under a Creative Commons Attribution 4.0 International License, which permits use, sharing, adaptation, distribution and reproduction in any medium or format, as long as you give appropriate credit to the original author(s) and the source, provide a link to the Creative Commons licence, and indicate if changes were made. The images or other third party material in this article are included in the article's Creative Commons licence, unless indicated otherwise in a credit line to the material. If material is not included in the article's Creative Commons licence and your intended use is not permitted by statutory regulation or exceeds the permitted use, you will need to obtain permission directly from the copyright holder. To view a copy of this licence, visit http://creativecommons.org/licenses/by/4.0/.

(c) The Author(s) 2021 